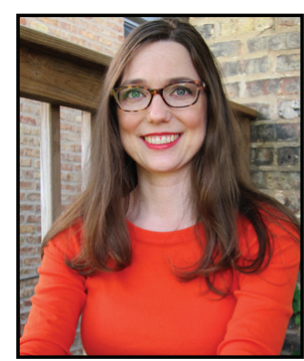

\section{Make No Little Plans}

1 ell it's time for the big plans: implementing reorganization of the round table.

Last winter, the GODORT working group on reorganization presented a plan on how to take the Government Documents Round Table into the next generation.

By accepting this report, the Steering Committee reaffirmed the mission of GODORT as a place that creates a community for the exchange of ideas for librarians working with government information, sponsors and supports innovative programming, acts as an advocate for government information by increasing communications with the larger community of information professionals, and contributes to the education and training of government information librarians.

Some of the recommendations have already been implemented. The report recommended that internal liaisons be eliminated. I did not appoint any internal liaisons for 2016-17.

Another of implemented recommendations was to pair down the conference schedule of meetings. This Midwinter meeting will have GODORT-sponsored meetings on two and a half days, and most committees will be meeting virtually before or after Midwinter.

The next part of the plan seems to be where it gets sticky. This is where the "Big Plans" need to be decided on and implemented. I believe we need to provide ample opportunities for members to contribute and be active in GODORT without being bogged down with business and procedures just because they are what we have been used to.

Most groups in ALA have been going in the direction of more discrete projects done by working groups, with fewer committee appointments. People want to add to a portfolio with accomplishments. Perhaps this is not all that radical. By adjusting the tasks of the group and streamlining the structure, I hope that our outcomes match our mission and vision.

As we get ready to move this process to membership votes at Midwinter Meetings and on the ALA Election ballot, I want to emphasize that even if it seems radical, our vision is to bring documents to the people: empowering users to engage with their government through increased access and transparency, and ensure long-term access to government information. Now is a time to stand up for Government Information.

\section{Note}

Column title: The full quotation from Daniel Burnham is "Make no little plans; they have no magic to stir men's blood and probably themselves will not be realized. Make big plans; aim high in hope and work." Quoted in Charles Moore, Daniel H. Burnham, Architect, Planner of Cities, vol. 2 (Boston; New York: Houghton Mifflin Company, 1921), 147. 